\title{
Protection of protein from bacterial degradation by submicron particles
}

\author{
Niels Henrik Borch*, David L. Kirchman** \\ College of Marine Studies, University of Delaware, Lewes, Delaware 19958, USA
}

\begin{abstract}
This study investigated how bacteria degrade protein that is adsorbed to or trapped within submicron particles designed to model those particles produced by protists grazing on bacteria and other picoplankton. The structure for some of these particles is hypothesized to be similar to liposomes, i.e. cell-like structures with lipid bilayers surrounding an aqueous center. To examine the degradation of liposome-like submicron particles, we prepared liposomes from phospholipids, a common constituent of all cellular membranes, and examined degradation of protein freely dissolved and in various associations with liposomes. Natural bacterial assemblages responded rapidly to addition of protein and could degrade most (92\%) of the truly dissolved protein (not associated with liposomes) within 72 to 90 h even though added concentrations were up to 1 order of magnitude greater than natural levels. In spite of the capacity for rapid utilization, protein degradation was substantially inhibited ( 3 -fold) by the presence of liposomes. Protein entrapped within the liposomes was protected the most, but adsorption to the outside of liposomes also decreased the degradability of protein. Degradation of liposomes appeared to be mainly due to bacteria, not heterotrophic protists. Our data support previous studies suggesting that labile compounds may be physically protected from degradation when entrapped within submicron particles. These results help explain the presence of dissolved membrane proteins and other cell wall material in the dissolved organic carbon pool of marine ecosystems.
\end{abstract}

KEY WORDS: Submicron particles $\cdot$ Colloids · Protein degradation · Dissolved lipids

\section{INTRODUCTION}

Submicron particles are abundant in aquatic systems and may play a variety of important roles in biogeochemical cycles (Koike et al. 1990, Longhurst et al. 1992). Because their collective surface area is large adsorption to submicron particles may be important in the transport and degradation of surface-active compounds and as sites for surface-dependent geochemical reactions. Although there have been studies of protists grazing on submicron particles (Tranvik et al 1993), relatively little is known about the degradation of these particles, especially by bacteria (Nagata \& Kirchman 1997).

- Present address: Freshwater Biological Laboratory, University of Copenhagen, 51 Helsingørsgade, DK-3400 Hillerød, Denmark

" Addressee for correspondence. E-mail: kirchman@udel.edu
Some submicron particles seem to be produced within microbial food webs, specifically by flagellates grazing on bacteria (Koike et al. 1990, Nagata \& Kirchman 1992, Tranvik 1994). Data presented by Nagata \& Kirchman (1992) suggest that the structure of some 'flagellate fecal pellets' is like that of liposomes, i.e. submicron particles consisting of membranes surrounding an aqueous center. These cell-like particles form spontaneously from membrane fragments (New 1990) produced during digestion and egestion. It seems likely that liposome-like particles could be produced during grazing by other organisms on non-bacterial prey. Viral lysis may also produce liposome-like particles (Shibata et al. 1997).

During their formation, liposomes are likely to entrap cellular material and effectively surround it with lipids (New 1990). Nagata \& Kirchman (1992) demonstrated that protein was entrapped within liposome-like particles produced during flagellate grazing 
on bacteria. These authors went on to hypothesize that entrapped material would be resistant to degradation by heterotrophic bacteria, but supporting data were not presented. If correct, the hypothesis could help explain the presence of membrane proteins (Tanoue et al. 1995, 1996) and other cell wall material (Aluwihare et al. 1997, McCarthy et al. 1998) in seawater and provide insights into the transformation of labile material to more refractory forms (Keil \& Kirchman 1994).

Other associations with liposome-like particles may also affect degradation of selected compounds. Nagata et al. (1998) recently showed that proteins within membranes are degraded more slowly than soluble proteins. Also, Nagata \& Kirchman (1996) demonstrated that protein adsorbed to submicron particles was degraded more slowly than free protein, although that study and others (Samuelsson \& Kirchman 1990, Taylor 1995) have used particles or other substrata with compositions far from those found in nature. The fate of protein adsorbed to or trapped within liposome-like structures is not clear.

It is not surprising that we do not how liposome-like particles are degraded because we know little about the formation and degradation of macromolecular complexes composed of different compounds. These complexes are likely to dominate the colloidal or high molecular weight dissolved organic matter (HMW DOM), which has been shown recently to be a dynamic component of the total DOM pool (e.g. Amon \& Benner 1996). It is conceivable that the turnover of complexes differs from that of individual dissolved compounds. For example, compounds in some sort of physical association with other organic material may be less available to degradation enzymes because of steric hindrance. Lee \& Wakeham (1992) proposed a double layer hypothesis in which outer layers of organic compounds protect internal material from chemical oxidation, a mechanism which may also apply to enzyme-mediated hydrolysis and eventual biological oxidation. The double-layer hypothesis could apply to organic complexes not organized into liposome-like structures.

The purpose of this study was to examine the double layer hypothesis and to test whether or not liposomes could protect proteins from degradation by natural bacteria. We used liposomes prepared mainly from phospholipids, an important part of all cellular membranes, as a model of flagellate fecal pellets. This welldefined model allowed us to control the composition and the properties of the submicron particles. We could either entrap protein within the liposomes or allow protein to sorb to the outside of the liposomes after they were formed. Our results indicate that even though liposomes could be degraded by natural bacterial assemblages, protein trapped within and adsorbed to liposomes was degraded substantially more slowly than free protein.

\section{MATERIALS AND METHODS}

Preparation of liposomes. Bovine serum albumin (BSA) was radioactively labeled by reductive methylation with $\mathrm{NaB}^{3} \mathrm{H}_{4}$, which labels terminal amino groups, primarily lysine (Tack et al. 1980). The labeled protein was separated from excess ${ }^{3} \mathrm{H}$ by precipitation with $5 \%$ (final conc.) trichloroacetic acid (TCA). Three to four precipitations were enough to remove $>99 \%$ of unbound label. The labeled protein had a specific activity of $0.03 \mu \mathrm{Ci} \mu^{-1}$. Keil \& Kirchman (1992) showed that methylated amino acids are not incorporated by bacteria upon degradation of the protein. They also showed degradation rates of ${ }^{3} \mathrm{H}$-methyl labeled protein to be equal to rates determined with uniformly labeled protein. Thus, the appearance of radioactivity in the TCA-soluble fraction is a measure of protein hydrolysis.

We used liposomes prepared from a commercially available kit (Sigma) as models of natural submicron particles. Liposomes were purchased as a dry powder (phosphatidylcholine: dicetyl phosphate: cholesterol, 63:18:9 molar ratio) and were prepared by suspension in artificial seawater (Samuelsson \& Kirchman 1990), followed by probe sonication for $10 \mathrm{~min}$ on ice and bath sonication for $1 \mathrm{~h}$. To entrap protein within the liposomes, ${ }^{3} \mathrm{H}$-protein was added at the time of suspension. To examine protein adsorbed to liposomes, ${ }^{3} \mathrm{H}$-protein was not added until the liposomes had been formed. The amount of protein in the free state not associated in any fashion with liposomes, adsorbed to the outside of liposomes, and entrapped within the liposomes varied among different batches of liposomes.

For some experiments we reduced the amount of free protein in the liposome preparation by ultrafiltration through a $100000 \mathrm{Da}$ nominal weight cut off filter (YM1000, Amicon) in a stirred cell (Amicon) pressurized with nitrogen. The filtration was continued until the original volume had been replenished 5 times with sterile artificial seawater. To determine the amount of protein entrapped within the liposomes and thus not readily available to bacterial degradation, we followed the degradation of protein by a protease (Pronase $\mathrm{K}$, Sigma). Since free protein without liposome was $100 \%$ degradable by Pronase K (see 'Results'), the amount of free protein in liposome preparations was estimated from the protein in these preparations that could be degraded by Pronase $K$. The protease test assumes that the protease is not able to penetrate inside the liposome. The protease $\left(100 \mu \mathrm{g} \mathrm{ml}^{-1}\right.$ final conc.) was 
added to the liposome suspension and the samples were incubated for 1.5 to $2 \mathrm{~h}$ at room temperature. After the incubation, BSA (final conc. $1 \mathrm{mg} \mathrm{ml}^{-1}$ ) was added as a carrier followed by TCA (final conc. $5 \%$ ) and the samples were mixed by vortexing. After incubating on ice for 10 to $15 \mathrm{~min}$, the sample was centrifuged for $15 \mathrm{~min}$ at $14000 \times \mathrm{g}$. The supernatant was then radioassayed to determine the amount of TCAsoluble activity. Liposome preparations incubated without protease served as a control for abiotic hydrolysis of protein

Degradation experiments. For each degradation experiment, duplicate bottles with natural seawater (from the Delaware Bay in April, September and October 1996) were amended with entrapped protein suspensions, absorbed protein, or protein alone, and incubated in the dark at room temperature on a shaking table. Over time samples were taken for total and TCA-soluble radioactivity. In some experiments bacterial production and abundance were also measured. Bacterial production was measured by the incorporation of ${ }^{14} \mathrm{C}$-leucine (Kirchman 1993). Triplicate samples and 1 killed control were incubated with 10 or $20 \mathrm{nM}$ ${ }^{14} \mathrm{C}$-leucine for $30 \mathrm{~min}$ to $1 \mathrm{~h}$. Bacterial abundance was estimated by the acridine orange direct count method (Hobbie et al. 1977).

Degradation of entrapped protein was estimated from total degradation minus degradation of free protein. Degradation of free protein in the entrapped treatment was assumed to equal the degradation rate of protein without liposomes, an assumption that is examined below. The fraction of entrapped protein that was degraded was calculated with the following equation:

$$
D_{\mathrm{E}}=\left(T_{\mathrm{E}}-T_{\mathrm{F}} \times F_{\mathrm{F}}\right) / F_{\mathrm{E}}
$$

where $D_{E}$ is percent degradation of entrapped protein alone, $T_{E}$ and $T_{F}$ are total percent degradation in entrapped and free protein incubations, respectively; these percentages are based on the total radioactivity in the various incubations. Finally, $F_{\mathrm{F}}$ and $F_{\mathrm{E}}$ are the fractions of free and entrapped protein, respectively, as estimated by the protease assay (see above). Since free protein was also present in the incubation with adsorbed protein, degradation of free protein was subtracted out using an equation similar to that given above. As with the entrapped treatment, the protease assay was used to estimate the amount of free protein in incubations with adsorbed protein

Bacterial degradation of lipids within liposomes was followed with liposomes labeled with ${ }^{14} \mathrm{C}$-lipids. For these experiments, liposomes were synthesized with phosphatidylcholine, 1,2-di[1-14 C)palmitoyl (112 mCi $\mathrm{mmol}^{-1}$, Amersham). Degradation was followed over time by measuring respiration, which was estimated as the sum of the loss of total activity in the incubation bottle (some $\mathrm{CO}_{2}$ was lost to the headspace) and the amount of the remaining activity that could be purged off with nitrogen after acidification.

We also examined the effect of liposome constituents on protein degradation. Equimolar amounts of glycerol, phosphate and choline ([2-hydroxyethyl]-trimethylammonium) were mixed with ${ }^{3} \mathrm{H}$-protein and subsequently added to a seawater sample. The degradation rates of protein were compared to a treatment with only ${ }^{3} \mathrm{H}$-protein.

\section{RESULTS}

\section{Degradation of entrapped protein}

Degradation of free protein and protein entrapped in liposomes by natural bacterial assemblages differed greatly (Fig. 1). Both the initial degradation rate and the total amount degraded were higher for free protein. During the first $30 \mathrm{~h}, 64 \%$ of the free protein was degraded compared to $22 \%$ of the entrapped. In the next $23 \mathrm{~h}$, an additional $14 \%$ of the free protein but only $4 \%$ of the entrapped protein was degraded. At the end of the incubation a 3 -fold higher percentage of free protein had been degraded compared to entrapped protein. It must be noted that the treatments with entrapped protein always contained some free unentrapped protein; protein was never completely entrapped during formation of the liposomes. The ini-

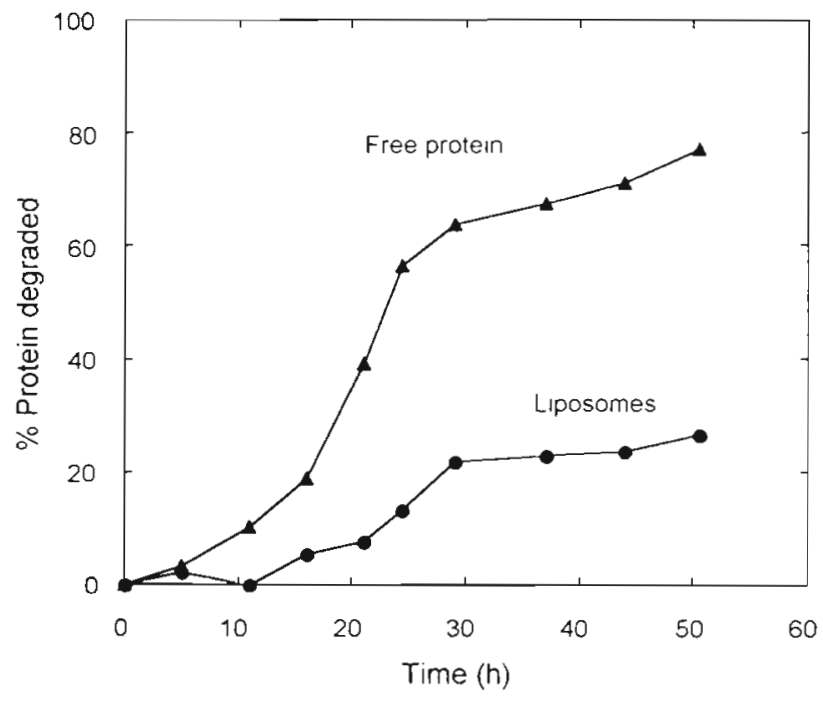

Fig. 1. Bacterial degradation of free ${ }^{3} \mathrm{H}$-protein or ${ }^{3} \mathrm{H}$-protein trapped within liposomes, separated from free protein by ultrafiltration (filter cutoff size of $100 \mathrm{kDa}$ ). The added protein concentration was $3.5 \mu \mathrm{g} \mathrm{ml} \mathrm{m}^{-1}$. Each point is the average of duplicate incubations. Variation between bottles was less than $5 \%$ 
Table 1. Effect of concentration on degradation rates and total amount of protein degraded in incubations with free protein and protein with liposomes. Initial degradation rates are based on the first $12 \mathrm{~h}$ of incubation and total degradation on $74 \mathrm{~h}$. Means of duplicate samples that differed by $<5 \%$

\begin{tabular}{|c|c|c|c|c|c|c|c|}
\hline \multirow{2}{*}{$\begin{array}{l}\text { Conc. } \\
\left(\mu \mathrm{gl}^{-1}\right)\end{array}$} & \multicolumn{2}{|c|}{ Initial rate $\left(\mu \mathrm{g} \mathrm{l}^{-1} \mathrm{~h}^{-1}\right)$} & \multirow[t]{2}{*}{$\%$ inhibition } & \multicolumn{2}{|c|}{ Total degradation $\left(\mu \mathrm{g} \mathrm{ml}^{-1}\right)$} & \multicolumn{2}{|c|}{$\%$ degradation } \\
\hline & Free & + liposomes ${ }^{d}$ & & Free & + liposomes ${ }^{a}$ & Free & + liposomes \\
\hline 0.4 & 36 & 23 & 36 & 0.30 & 0.20 & 89 & 53 \\
\hline 1.6 & 61 & 44 & 28 & 1.68 & 0.86 & 93 & 59 \\
\hline 3.3 & 99 & 57 & 42 & 3.32 & 1.77 & 94 & 58 \\
\hline 4.2 & 101 & 66 & 35 & 3.57 & 2.53 & 90 & 56 \\
\hline 4.8 & 109 & 70 & 36 & 4.64 & 2.54 & 95 & 54 \\
\hline
\end{tabular}

tial, relatively rapid degradation in samples with entrapped protein appears to be due to degradation of free protein.

We examined how protein and liposome concentrations affected initial degradation rates and the total amount of protein degradation. Degradation rates increased with increasing amounts of protein for both treatments as expected, but initial degradation rates for protein with liposomes was on average $36 \%$ ( $\mathrm{SD}=$ $5 \%, \mathrm{n}=5$ ) lower than the free protein rates (Table 1 ). For all concentrations, only $56 \%(\mathrm{SD}=2.5 \%, \mathrm{n}=5)$ of the liposome protein was degraded while $92 \%$ (SD = $2.6 \%, n=5$ ) of the free protein had been degraded at the end of the incubation (means of data in Table 1), even though the amount of protein (and liposomes) added spanned more than 1 order of magnitude. The results indicate that $44 \%$ of the protein was protected by the liposomes from degradation. Natural bacterial assemblages have a large capacity for protein degradation, as indicated by the nearly complete degradation of all free protein over $74 \mathrm{~h}$ even at high concentrations. If the protein is available, it will be degraded.

The results presented above suggest that liposomes are able to physically protect protein from degradation. The inhibition of protein degradation is not due to competitive inhibition because the addition of liposome constituents had no effect on protein degradation (Fig. 2). Furthermore, bacterial abundance and activity as measured by ${ }^{14} \mathrm{C}$-leucine incorporation was enhanced in the presence of liposomes (data not shown), indicating that liposomes did not have any direct inhibitory effect on bacterial activity. Even though bacterial activity was enhanced in the presence of liposomes, degradation of liposome-trapped protein was lower than degradation of free protein. These data are consistent with our hypothesis that liposomes physically protect protein from degradation by bacteria.

We examined whether bacteria or larger organisms were more important in protein degradation. There was no difference in degradation rates between unfiltered water and $1.0 \mu \mathrm{m}$ filtered water in any treatment
(Fig. 3), indicating that degradation was primarily due to bacteria. Even though bacterial abundance was lower in $1.0 \mu \mathrm{m}$ filtrates, $100 \%$ of the free protein in both unfiltered and filtered water was degraded, supporting our earlier observation that natural bacteria are capable of degrading large amounts of protein. The lack of a difference between unfiltered water and $1.0 \mu \mathrm{m}$ filtrate in entrapped protein degradation also indicates that larger organisms did not make more free protein available for the bacteria by degrading the liposomes. The addition of liposomes caused a substantial increase in bacterial numbers and subsequently in microflagellates. At the end of the incubation bacterial abundance in the treatments with liposomes was 2- to 13-fold higher than in the incubation with protein alone (data not shown).

Because the entrapped treatments also contained free, unentrapped protein (see above), we had to correct for the degradation of free protein. We used pro-

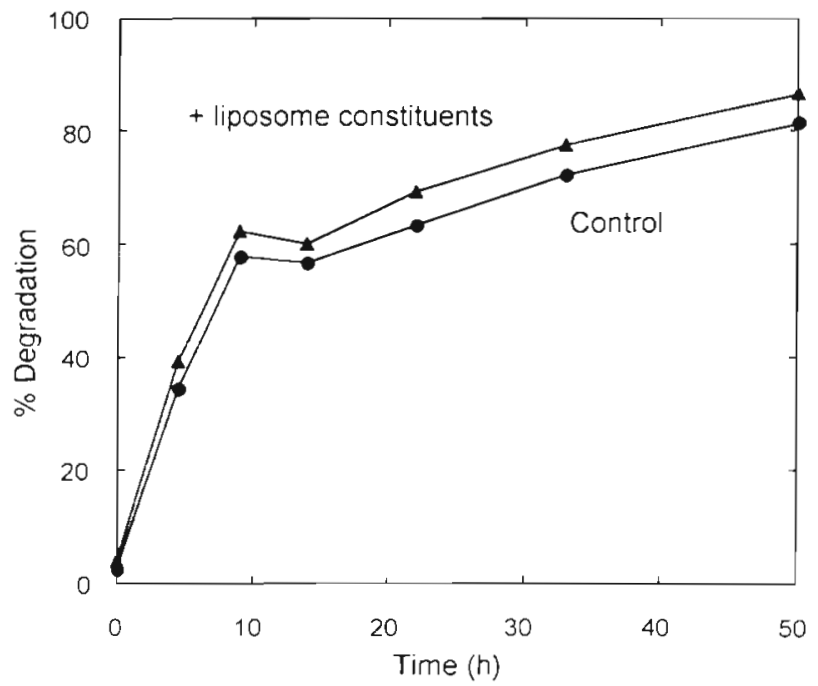

Fig. 2. Protein degradation with and without the chemical constituents of liposomes. The added protein concentration was $0.4 \mu \mathrm{g} \mathrm{m}^{-1}$ Each point is the average of duplicate incubations. Variation between bottles was less than $5 \%$ 


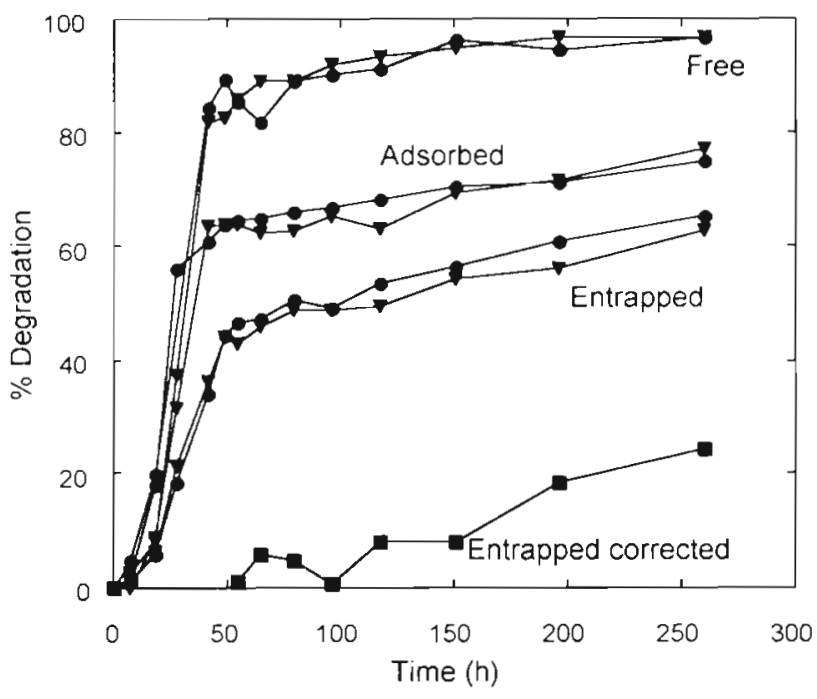

Fig. 3. Protein degradation in unfiltered $(\mathbf{v})$ and $1.0 \mu \mathrm{m}$ filtered (-) seawater. Also shown are the corrected values for degradation of entrapped protein (see text). The added protein concentration was $3.8 \mu \mathrm{g} \mathrm{ml}^{-1}$ Each point represents the average of duplicate incubations. Variation between bottles was less than $5 \%$

tease digestion to measure in each treatment the amount of free protein by measuring the protein degradable by protease. Degradation of entrapped protein was then calculated for each time point (see 'Materials and methods'). When corrected for degradation of free protein, it appears that degradation of entrapped protein did not start until all the free protein had been degraded (Fig. 3), although we cannot rule out low initial levels of entrapped protein degradation. Degradation in the entrapped treatment leveled off after approximately $45 \%$ of all protein had been degraded; protease digestion indicated that free protein comprised $46 \%$ of the total, indicating that bacteria had degraded only the free protein. From $49 \mathrm{~h}$ to the end of the incubation $(260 \mathrm{~h})$, the degradation rate of entrapped protein was $0.12 \% \mathrm{~h}^{-1}$ (SE $=0.01, \mathrm{r}^{2}=$ 0.956), which is more than one order of magnitude lower than the initial degradation rate of $1.96 \% \mathrm{~h}^{-1}$ $\left(\mathrm{SE}=0.26, \mathrm{r}^{2}=0.934\right)$ for free protein.

\section{Degradation of adsorbed protein}

We also examined the effect of sorption on protein degradation because natural and model submicron particles have large surface areas available for adsorption processes. There was no difference in the initial degradation for adsorbed and free protein (Fig. 3), but degradation of adsorbed protein leveled off after approximately $60 \%$ had been degraded. This is below what the protease assay had indicated was free protein

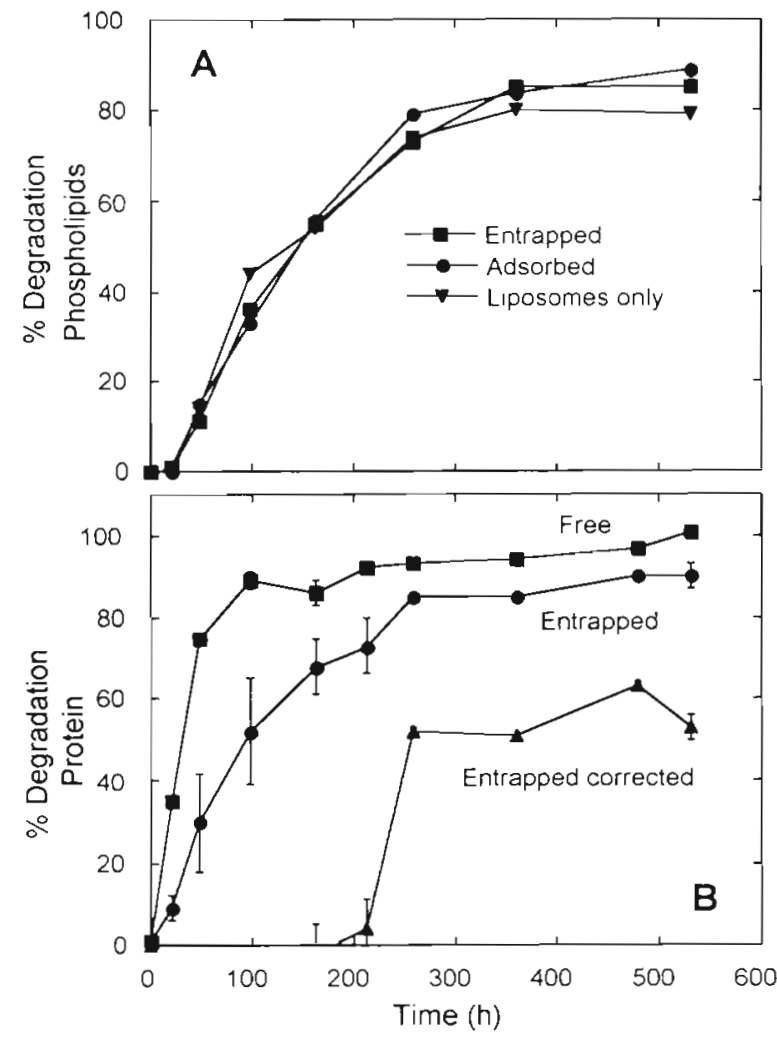

Fig. 4. Degradation of (A) liposomes and (B) protein. The added protein concentration was $0.4 \mathrm{\mu g} \mathrm{m}^{-1}$. Each point represents the average of duplicate incubations. Bars indicate range of duplicates when it exceeded the size of the points

$(74 \%)$, suggesting that some initially free protein sorbed onto liposomes and became protected from degradation. After correction for the degradation of free protein, little if any adsorbed protein seems to have been degraded. The slope of the regression line $\left(0.03 \% \mathrm{~h}^{-1}\right)$ was not significantly different from zero $(\mathrm{p}>0.05)$.

\section{Degradation of liposomes}

One possible explanation for the observed protection of protein by liposomes is that the bacteria were not able to degrade liposomes and thus could not gain access to entrapped protein. To examine simultaneous lipid and protein degradation, we synthesized liposomes with ${ }^{14} \mathrm{C}$-phospholipids and entrapped ${ }^{3} \mathrm{H}$-protein. The phospholipids were in fact degraded as measured by respired ${ }^{14} \mathrm{C}$ (Fig. 4A). After a brief lag period, lipids were degraded until $75 \%$ was respired after $250 \mathrm{~h}$. Only little further respiration was measured for the rest of the incubation. There was no difference in lipid degradation when liposomes were incubated alone or with protein (Fig. 4A), but the presence of 
liposomes did inhibit the degradation of protein as observed before (Fig. 4B). These results indicate that liposomes can protect protein from degradation, but protein does not provide protection for liposomes. Although degradation rates of protein and lipids can not be compared directly due to the different methods of detection, it seems that lipids were degraded more slowly than free protein. For free protein, $90 \%$ was degraded in less than $100 \mathrm{~h}$ (Fig. 4B), while only $40 \%$ of the lipids was respired during the same period (Fig. 4A).

After $22 \mathrm{~d}$ of incubation about $10 \%$ of the entrapped protein was undegraded but no free protein remained (Fig. 4B). When degradation in the entrapped treatment was corrected for the degradation of free protein, degradation of entrapped protein did not start until after $200 \mathrm{~h}$ of incubation (Fig. 4B), at which time approximately $60 \%$ of the lipids had been respired; as in other experiments, we cannot completely rule out low levels of entrapped protein degradation. About 10 to $15 \%$ of initial lipid ${ }^{14} \mathrm{C}$ and protein ${ }^{3} \mathrm{H}$ remained at the end of the incubation ( $3 \mathrm{wk})_{i}$ the ${ }^{3} \mathrm{H}$ radioactivity was still in the high molecular weight fraction, since it could be precipitated by TCA, although it may not necessarily have been protein. Also, it is unclear if the remaining ${ }^{14} \mathrm{C}$ activity was still associated with phospholipids, incorporated into biomass, or transformed to other compounds.

\section{DISCUSSION}

The purpose of this study was to examine how protein degradation by natural bacteria is affected by association with those submicron particles that have structures like liposomes, i.e. lipid-rich membranes surrounding an internal aqueous center. These submicron particles are produced during grazing by some protists on heterotrophic bacteria (Nagata \& Kirchman 1992) and probably on other picoplankton, as well as possibly by viral lysis (Shibata et al. 1997). Liposomelike submicron particles can entrap compounds such as protein that otherwise would be readily degraded by bacteria (Nagata \& Kirchman 1992). We used model submicron particles, i.e. synthetic liposomes, in an attempt to elucidate how physical interactions between different compounds affect degradation in natural aquatic systems.

Our data suggest that liposomes physically protect entrapped protein from degradation by bacteria. The physical protection hypothesis is supported by the difference in degradation of adsorbed protein versus that of entrapped protein, the 2 treatments with liposomes. These 2 treatments had the same organic additions, but differed in when protein was added during prepa- ration of the liposomes. In the entrapped treatment, protein was added as the liposomes were formed, and thus protein was trapped inside the liposomes. In the adsorbed treatment, protein was not added until after the liposomes were formed and, consequently, all protein was on the outside of the liposomes. We found that entrapped protein was degraded more slowly than adsorbed protein by bacteria. Since the physical arrangement, but not the chemical composition, of liposome-protein complexes in these 2 treatments differed, these data indicate that the liposomes can physically protect the entrapped protein. Furthermore, we found that hydrolysis of entrapped protein by proteases was about equal initially to that of bacterial degradation, suggesting that liposomes inhibit protein degradation by interfering with bacterial ectoproteases.

Several control experiments and measurements helped rule out alternative explanations. Addition of liposomes stimulated bacterial activity and abundance, indicating that toxic compounds were not added along with the liposomes to the incubations. Another alternative explanation is that the addition of another carbon source caused a competitive inhibition of protein degradation; perhaps bacteria switched from protein degradation to lipid degradation. However, addition of liposome constituents did not affect degradation of free protein, indicating that bacteria did not switch from one carbon source to another. In addition, natural bacteria are capable of degrading large amounts of protein. Although added protein concentrations varied by more than 1 order of magnitude in our saturation experiment, natural bacteria responded immediately to the enrichment, and all free protein was degraded within $72 \mathrm{~h}$ regardless of the amount added. These results indicate that if free protein was present, it was degraded regardless of the presence of other compounds. In short, mechanisms other than our physical protection hypothesis do not explain why protein associated with liposomes is degraded more slowly than free protein.

We used natural material as surfaces to examine the effect of adsorption on protein degradation. This is in contrast to most other studies, which predominantly used solid artificial surfaces. Nagata \& Kirchman (1996) found that adsorption to polystyrene beads reduced the availability of protein to bacteria, whereas Taylor (1995) used glass beads and hypothesized that protein adsorbed to surfaces can be as bioavailable as protein in solution. These studies came to different conclusions perhaps because they used surfaces with different hydrophobicities. Samuelsson \& Kirchman (1990) showed that percent degradation of adsorbed protein decreased with increasing surface hydrophobicity. The surface of liposomes is hydrophilic because the polar 
headgroups in the phospholipids are facing the aqueous surroundings. Thus, although the polar heads of liposomes should resemble the hydrophilic glass surfaces used by Taylor (1995), our results indicate that even a hydrophilic surface may reduce degradation of adsorbed protein. Adsorption has been hypothesized to be an important factor in geochemical preservation of organic matter in sediments (Keil et al. 1994).

Not much is known about concentrations and the turnover of lipids in marine systems. Only a few studies have measured concentrations of lipids. 'Dissolved' (less than $1 \mu \mathrm{m}$ ) lipid concentrations are typically 9 to $190 \mu \mathrm{g} \mathrm{l}^{-1}$ (Parrish \& Wangersky 1988, Andersson et al. 1993, Gérin \& Goutx 1994) in surface waters, and concentrations of particulate lipids are typically 2 to 10 times lower than dissolved concentrations (Parrish \& Wangersky 1988, Liu et al. 1998). But the division between dissolved and particulate lipids may be misleading as it is based on filtration. Koike et al. (1990), for example, showed that large numbers of submicron particles with a diameter larger than $0.38 \mu \mathrm{m}$ were able to pass a $0.2 \mu \mathrm{m}$ filter. Even though lipids are only a minor part of total organic matter in the ocean, their hydrophobic nature may make them an important part. It is useful to remember that lipids make up a small fraction $(<10 \%)$ of the biomass of even living cells (Ingraham et al. 1983). The presence of lipid components in old sediments suggests that at least parts of lipids are not easily degraded in natural systems.

Even fewer studies have examined the turnover of lipids. Martinez et al. (1996) found lipase activity in all 44 marine bacteria they isolated, indicating that the capacity to degrade lipids is common in marine bacteria. Using an analog for lipids, Gajewski et al. (1993) measured lipase activity in an eutrophic lake and estimated turnover times of 37 to $376 \mathrm{~h}$. Turnover of lipids is generally much slower than turnover of protein in the Delaware Bay (Borch \& Kirchman unpubl. data). The results presented here also suggest that lipids are degraded more slowly than free protein.

Our results and other studies (Nagata \& Kirchman 1996. Nagata et al. 1998) help explain the presence of cell membrane and wall materials in the HMW DOM pool (Tanoue et al. 1995, Aluwihare et al. 1997. McCarthy et al. in press). The general conclusion from these studies is that components like protein are less labile when associated with submicron particles than when freely dissolved. The possible associations include adsorption (this study; Nagata \& Kirchman 1996), integration within lipid bilayers (Nagata et al. 1998), and entrapment in an aqueous center surrounded by lipid bilayers (this study). All 3 types of associations appear to impede degradation because of steric hindrance of ectoenzymes probably bound to the outer membrane of heterotrophic bacteria. Some of these membrane and wall components, however, may be intrinsically refractory (Puel et al. 1987, Gelin et al. 1996), regardless of associations with submicron particles.

Submicron particles such as those examined here may facilitate the transformation of labile compounds like protein into more refractory forms. Keil \& Kirchman (1994) showed that protein aged abiotically for as little as 7 h was degraded more slowly than fresh protein. They hypothesized that the initial, rapid aging effect was due to adsorption to colloids (submicron particles), an hypothesis that is supported by our results and others (Nagata \& Kirchman 1996). However, the longer-term aging effect observed by Keil \& Kirchman (1994) cannot be explained by adsorption effects. One possibility is that the protein is somehow transformed into more refractory forms while in association with submicron particles. Our experiments present some evidence for this transformation. We observed that liposome-associated protein was never completely degraded even in the longest incubation of more than 3 wk. Also, there was ${ }^{14} \mathrm{C}$ organic material (originally added as ${ }^{14} \mathrm{C}$-lipid) left at the end of the incubation. It is possible that some relatively refractory organic matter was produced by reactions occurring within liposomes.

In addition to protecting labile compounds from immediate degradation, liposome-like submicron particles may act as reaction chambers and facilitate reactions that transform labile compounds to more refractory forms. Nagata \& Kirchman (1992) hypothesized that several otherwise soluble labile compounds could be trapped within submicron particles produced by heterotrophic protists. In addition to being chemically heterogeneous, concentrations inside submicron particles are likely to be much higher than in the surrounding water. These high concentrations of several different compounds would facilitate diagenetic reactions that may create refractory compounds (Yamamoto \& Ishiwatari 1989).

Our results are consistent with the double layer hypothesis of Lee \& Wakeham (1992), which could apply even to submicron particles and HMW DOM not organized into liposome-like structures. The hypothesis is simply that the presence of one organic layer can impede the degradation of other material not exposed directly to exoenzymes. Although more labile than the rest of the DOM pool (Amon \& Benner 1996), selected components of the HMW DOM could be relatively refractory because they are less available to bacterial ectoenzymes, as shown here for protein associated with liposomes. Only a small fraction of total HMW DOM needs to be protected in order to contribute substantially to the formation of refractory or semi-refractory DOM in oceanic waters. 
Acknowledgements. This work was supported by the National Science Foundation. We thank Toshi Nagata for his contribution to several phases of this work.

\section{LITERATURE CITED}

Aluwihare LI, Repeta D, Chen R (1997) A major biopolymeric component to dissolved organic carbon in surface sea water. Nature 387:166-169

Amon R, Benner R (1996) Bacterial utilization of different size classes of dissolved organic matter. Limnol Oceanogr 41: $41-51$

Andersson A, Selstam E, Hagström $\AA$ (1993) Vertical transport of lipid in seawater. Mar Ecol Prog Ser 98:149-155

Gajewski A, Chróst RJ, Siuda W (1993) Bacterial lipolytic activity in an eutrophic lake. Arch Hydrobiol 128:107-126

Gelin F, Boogers I, Noordeloos AAM, Sinninghe Damsté JS, Hatcher PG, de Leeuw JW (1996) Novel, resistant microalgal polyethers: an important sink of organic carbon in the marine environment? Geochim Cosmochim Acta 60: $1275-1280$

Hobbie JE, Daley RJ, Jasper S (1977) Use of Nuclepore filters for counting bacteria by fluorescence microscopy. Appl Environ Microbiol 33:1225-1228

Ingraham JL, Maaloe O, Neidhardt FC (1983) Growth of the bacterial cell. Sinauer Assoc Inc, Sunderland, MA

Keil RG, Kirchman DL (1992) Bacterial hydrolysis of protein and methylated protein and its implications for studies of protein degradation in aquatic systems. Appl Environ Microbiol 58:1374-1375

Keil RG, Kirchman DL (1994) Abiotic transformation of labile protein to refractory protein in seawater. Mar Chem 45: $187-196$

Keil RG, Montlucon DB, Prahl FG, Hedges JI (1994) Sorptive preservation of labile organic matter in marine sediments. Nature 370:549-552

Kirchman DL (1993) Leucine incorporation as a measure of biomass production by heterotrophic bacteria. In: Kemp P, Sherr BF, Sherr EB, Cole JJ (eds) Current methods in aquatic microbial ecology. Lewis, Boca Raton, p 509-512

Koike I, Hara S, Terauchi K, Kogure K (1990) Role of submicrometre particles in the ocean. Nature 345:242-244

Lee C, Wakeham SG (1992) Organic matter in the water column: future research challenges. Mar Chem 39:95-118

Liu Q, Parrish CC, Helleur R (1998) Lipid class and carbohydrate concentrations in marine colloids. Mar Chem 60: $177-188$

Longhurst AR, Koike I, Li WKW, Rodriguez J, Dickie P, Kep[k]ay P, Partensky F, Bautista B, Rutz J, Wells M, Bird DF (1992) Sub-micron particles in northwest Atlantic shelf water. Deep-Sea Res I 39:1-7

Martinez J, Smith DC, Steward GF, Azam F (1996) Variability in ectohydrolytic enzyme activities of pelagic marine bac-

Editorial responsibility: Farooq Azam,

La Jolla, California, USA teria and its significance for substrate processing in the sea. Aquat Microb Ecol 10:223-230

McCarthy MD, Hedges JI, Benner R (1998) Major bacterial contribution to marine dissolved organic nitrogen. Science $281: 231-234$

Nagata T, Kirchman DL (1992) Release of macromolecular organic complexes by heterotrophic marine flagellates. Mar Ecol Prog Ser 83:233-240

Nagata T, Kirchman DL (1996) Bacterial degradation of protein adsorbed to model submicron particles in seawater. Mar Ecol Prog Ser 132:241-248

Nagata T, Kirchman DL (1997) Roles of submicron particles and colloids in microbial food webs and biogeochemical cycles within marine environments. Adv Microb Ecol 15: $81-103$

Nagata T, Fukuda R, Koike I, Kogure K, Kirchman DL (1998) Degradation by bacteria of membrane and soluble protein in seawater. Aquat Microb Ecol 14:29-37

New RRC (ed) (1990) Liposomes: a practical approach. Oxford University Press, New York

Parrish CC, Wangersky PJ (1988) Iatroscan-measured profiles of dissolved and particulate marine lipid classes over the Scotian Slope and in Bedford Basin. Mar Chem 23:1-15

Puel F, Largeau C. Giraud G (1987) Occurrence of a resistant biopolymer in the outer walls of the parasitic alga Prototheca wickerhamii (Chlorococcales): ultrastructural and chemical studies. J Phycol 23:649-656

Samuelsson MO, Kirchman DL (1990) Degradation of adsorbed protein by attached bacteria in relationship to surface hydrophobicity. Appl Environ Microbiol 56: $3643-3648$

Shibata A, Kogure K, Koike I, Ohwada K (1997) Formation of submicron colloidal particles from marine bacteria by viral infection. Mar Ecol Prog Ser 155:303-307

Tack BF, Dean J, Eilat D, Lorenz PE, Schechter A (1980) Tritium labelling of proteins to high specific activity by reductive methylation. J Biol Chem 255:8842-8847

Tanoue E, Nishiyama S, Kamo M, Tsugita A (1995) Bacterial membranes: possible source of a major dissolved protein in seawater. Geochim Cosmochim Acta 59:2643-2648

Tanoue E, Ishii M, Midorikawa T (1996) Discrete dissolved and particulate proteins in oceanic waters. Limnol Oceanogr 41:1334-1343

Taylor GT (1995) Microbial degradation of sorbed and dissolved protein in seawater. Limnol Oceanogr 40:875-885

Tranvik L (1994) Colloidal and dissolved organic matter excreted by a mixotrophic flagellate during bacterivory and autotrophy. Appl Environ Microbiol 60:1884-1888

Tranvik LJ, Sherr EB, Sherr BF (1993) Uptake and utilization of 'colloidal DOM' by heterotrophic flagellates in seawater. Mar Ecol Prog Ser 92:301-309

Yamamoto S, Ishiwatari R (1989) A study of the formation mechanism of sedimentary humic substances-II. Protein-based melanoidin model. Org Geochem 14:479-489

Submitted: August 11, 1997; Accepted: July 11, 1998

Proofs received from author(s): December 17, 1998 